\title{
Mobile applications in surgical patient health education: an integrative review
}

\author{
Aplicativos de celular na educação em saúde do paciente cirúrgico: \\ uma revisão integrativa \\ Aplicaciones de celular en la educación en salud del \\ paciente quirúrgico: una revisión integrativa
}

How to cite this article:

Machado RCG, Turrini RNT, Sousa CS. Mobile applications in surgical patient health education: an integrative review. Rev Esc Enferm USP. 2020;54:e03555. DOI: http://dx.doi.org/10.1590/S1980-220X2018032803555

\section{Rafaela Cristina Gomes Machado ${ }^{1}$ \\ Ruth Natalia Teresa Turrini² \\ Cristina Silva Sousa ${ }^{2}$}

${ }^{1}$ Universidade de São Paulo, Escola de Enfermagem, São Paulo, SP, Brazil.

${ }^{2}$ Universidade de São Paulo, Escola de

Enfermagem, Departamento de Enfermagem Médico-Cirúrgica, São Paulo, SP, Brazil.
Corresponding author:

Rafaela Cristina Gomes Machado

Av. Dr. Enéas de Carvalho, 419, Cerqueira César

CEP 05403-000 - São Paulo, SP, Brazil

rafaela.cristina.machado@usp.br

\section{ABSTRACT}

Objective: To analyze the scientific literature produced on health education through mobile applications for surgical patients. Method: An integrative literature review performed through consultation in the following portals and/or databases: VHL; PubMed; Web of Science; Scopus; LILACS and CINAHL. The search was guided by the question: "What is the evidence on the use of mobile applications in the health education of surgical patients?" conducted from July to September 2017, including articles published from the year 2000 to 2017. Results: Five articles published in international journals in English with varied methodological designs were selected. Among the studies found, $60 \%$ used an educational intervention through smartphone applications in the pre and postoperative periods, and $40 \%$ of the studies had an evidence level of $2 \mathrm{~B}$. Conclusion: The studies showed that the use of smartphone applications in educating and guiding surgical patients was effective. However, there is still a gap in studies which demonstrate surgical patient education through smartphone applications.

\section{DESCRIPTORS}

Perioperative Care; Health Education; Mobile Applications; Smartphone; Perioperative Nursing; Review. 


\section{INTRODUCTION}

Health education has dimensions which encompass several areas of daily life and it directs the individual, the community and society to perform self-care when contemplating the political, collective, religious and cultural areas. Disseminating health education means transmitting information, requiring a theoretical-scientific basis of its issuer which must have all the possible resources to achieve its goal of stimulating, raising awareness and mobilizing the recipient of information to confront situations which may compromise their welfare ${ }^{(1)}$.

Promoting health education becomes a continuous process of inquiry, reflection and questioning by the professionals who implement this practice, especially nurses who work in the various spheres of health services. The knowledge transferred by these professionals aims to assist self-care actions and stimulate the prevention of diseases and health problems through such actions. Education is present in personal contact, regardless of the environment, and can be aided by mechanisms that facilitate its comprehension through printed materials, educational technologies and the Internet, which is currently the most widespread means of communication ${ }^{(1-2)}$.

In the context of the surgical patient, guidance can be performed through educational actions with accessible language, aiding in clarifying questions and providing education regarding the perioperative period. The perioperative period is understood as the time span which comprises the following steps: immediate preoperative; trans-operative; intraoperative; anesthetic recovery and immediate postoperative $e^{(2-3)}$.

The use of leaflets, explanatory brochures and even oral guidance are the most widespread means in educational action. But with technological advancement, one now sees the use of other educational tools such as mobile/tablet applications which have proven to be a trend between professionals and patients, evidencing adherence to educational models via smartphones ${ }^{(4)}$.

Based on this scenario, this study aims to analyze the scientific literature produced on health education through mobile smartphone applications for surgical patients.

\section{METHOD}

\section{StUdi DESIGN}

The methodology employed in this study is an "Integrative Literature Review, a research method which uses evidence-based practice, synthesizes available research on a given subject, and enables practice to be guided by scientific knowledge"(5).

The following predictive steps of an integrative review were implemented in order to perform this study: "identify the theme and elaborate the guiding question, conduct a search in the literature using inclusion and exclusion criteria, define the information to be extracted from the selected studies through a previously constructed bibliographic form, data collection, perform an evaluation implementing a critical analysis of the studies included in the review, discuss the results and present the integrative review"(5).

\section{DATA COlleCtion}

The search was guided by the question "What is the evidence on the use of mobile applications in the health education of surgical patients?" carried out from July to September 2017, including articles published from 2000 to 2017. The following databases and/or portals were used to select the articles: Biblioteca Virtual em Saude (BVS); National Library of Medicine (PubMed); Web of Science; Scopus; Literatura Latino-Americana e do Caribe em Ciência da Saúde (LILACS) and the Cumulative Index to Nursing and Allied Health Literature (CINAHL).

Inclusion criteria were: articles published in Portuguese, English and Spanish that reported the use of mobile applications for health education, available in full text formats. Exclusion criteria were: studies with other educational technologies such as brochures, video or oral communications, and those which did not respond to the objective of this review.

The following Descriptors in Health Sciences (DECS) and Medical Subject Headings (MESH) were used for the search: "Education materials", "Health education", "Patient education", "Smartphone" or "Smart Phone", "Surgery", "Cell Phone", "Mobile Phone", "Surgical patients", "Mobile Applications" and the term "Education intervention". Controlled descriptors are considered to be standardized terms, defined by experts. Therefore, the selected descriptors from the indexed vocabulary represented the focal point of the work.

Strategies were combined in different ways in order to achieve a broad search due to the access characteristics of the selected databases, "having the study question and the previously established inclusion criteria as a guiding axis" (Chart 1$)^{(6)}$.

Chart 1 - Search strategies according to database/portal.

\begin{tabular}{|c|c|}
\hline Database & Search structure \\
\hline BVS & $\begin{array}{l}\text { Patient education AND smartphone } \\
\text { Education intervention AND mobile phone AND } \\
\text { surgical patients } \\
\text { ("Smartphone" OR "Mobile Phone") AND (Orientation } \\
\text { OR Advice) AND ("Pacientes Cirúrgicos" OR "Paciente } \\
\text { Cirúrgico" OR "Surgical Patients" OR "Surgical Patient") }\end{array}$ \\
\hline PubMed & $\begin{array}{l}\text { (“"Mobile Applications" [Mesh] OR "Mobile } \\
\text { Applications"[tiab])) AND surgery }\end{array}$ \\
\hline Scopus & $\begin{array}{c}\text { (Smartphone OR "Mobile Phone" OR "Cell Phone" } \\
\text { OR Cellphone OR "Smart Phone") AND (Patient* AND } \\
\text { Surgery) }\end{array}$ \\
\hline $\begin{array}{l}\text { Web of } \\
\text { Science }\end{array}$ & $\begin{array}{c}\text { (Smartphone OR "Mobile Phone" OR "Cell Phone" } \\
\text { OR Cellphone OR "Smart Phone") AND (Patient* AND } \\
\text { Surgery) }\end{array}$ \\
\hline LILACS & $\begin{array}{l}\text { (Smartphone OR "Mobile Phone" OR "Cell Phone" } \\
\text { OR Cellphone OR "Smart Phone") AND (Patient* AND } \\
\text { Surgery) }\end{array}$ \\
\hline CINAHL & $\begin{array}{l}\text { (Smartphone OR "Mobile Phone" OR "Cell Phone" } \\
\text { OR Cellphone OR "Smart Phone") AND (Patient* AND } \\
\text { Surgery) }\end{array}$ \\
\hline Medline & $\begin{array}{c}\text { (Smartphone OR "Mobile Phone" OR "Cell Phone" } \\
\text { OR Cellphone OR "Smart Phone") AND (Patient* AND } \\
\text { Surgery) }\end{array}$ \\
\hline
\end{tabular}




\section{DATA ANALYSIS}

Studies published in the national and international scientific literature were analyzed by title and abstract. Data were collected and analyzed using an instrument adapted from the instrument created in a positioning injury study ${ }^{(6)}$. Therefore, the authors employed the following: identify the original article and methodological characteristics of the study, evaluate the methodological rigor, the interventions measured and the results found. The instrument was adapted to the object of the present investigation, containing the following items: article title, journal title, authors, country, language, publication year, study type, research objective or question, study population, study period, intervention, evaluation method, measuring instrument, statistical analysis, outcome and conclusion.

We used the Oxford level of evidence ${ }^{(7)}$ for the methodological evaluation of the selected studies, in which the study evidence is classified into recommendation grades of $1 \mathrm{a}, 1 \mathrm{~b}, 1 \mathrm{c}$, 2a, 2b, 2c, 3a, 3b, 4 and 5, as well as in the following domains: therapy, prevention, etiology and harm; prognosis; diagnosis; prevalence studies and differential diagnosis; economic and decision. Thus, the studies were categorized according to the degree of recommendation and the respective domain described on the scale, characterizing each study according to the employed method. A synoptic table was then prepared to present the synthesis of the articles containing the following characteristics: study code, sample, objective, intervention, measuring instrument, result and level of evidence.

The search in the selected databases resulted in 1,374 articles, from which 55 were excluded because they were duplicates, remaining 1,319 articles; 1,293 articles were removed after reading the titles and abstracts because they did not meet the inclusion criteria, leaving 26 articles. From these, 21 articles were fully evaluated and excluded because they did not answer the guiding question of this review. Thus, five articles were selected that met the inclusion criteria at the end of this analysis process and constituted the final sample. Figure 1 describes the article selection and inclusion process.

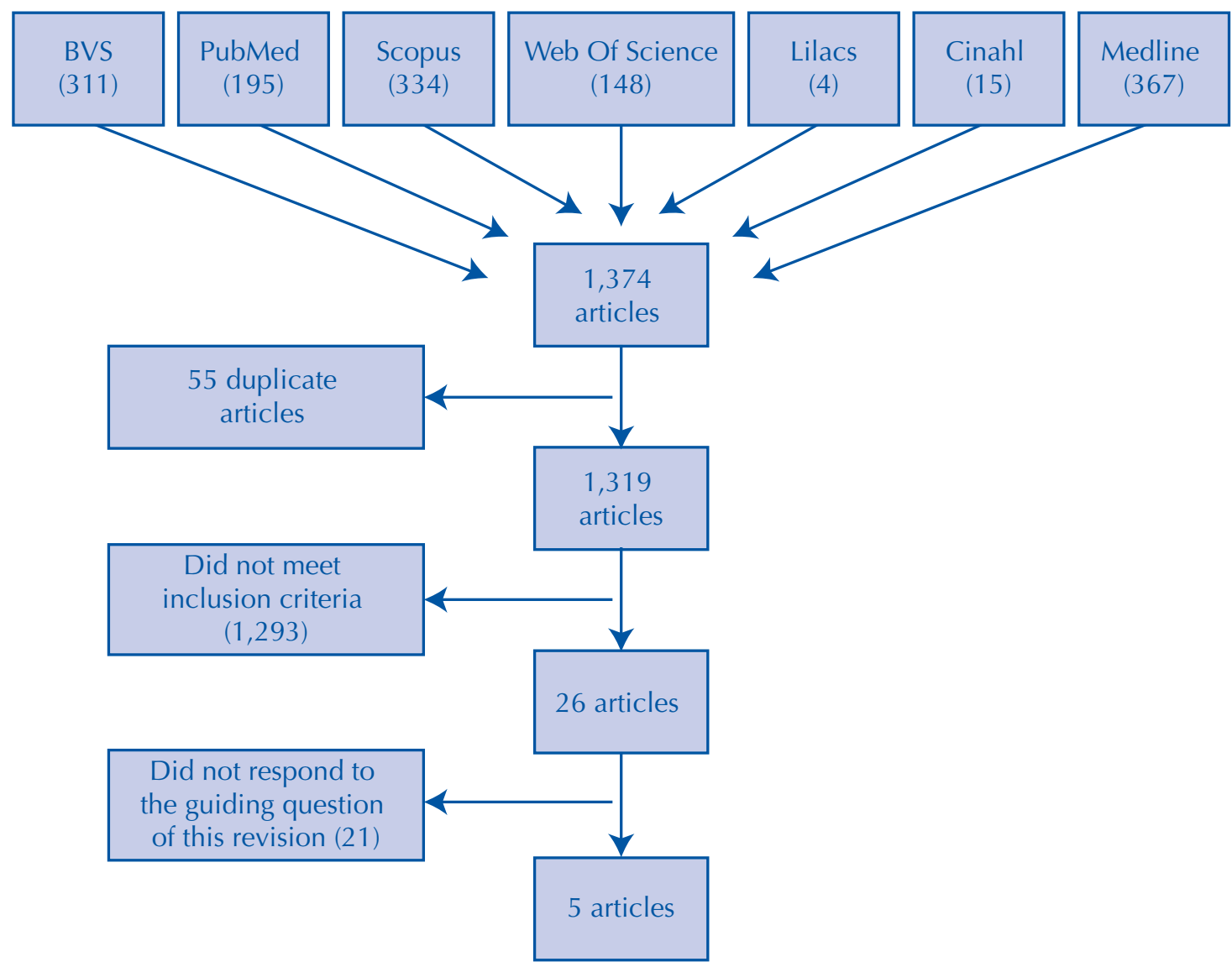

Figure 1 - Selection process and inclusion of the articles.

\section{RESULTS}

The articles included in this review were published in the English language between 2015 and 2017, highlighting the years 2016 and 2017, both with $40 \%$ of publications. The studies were published in the journals: Obes Surg ${ }^{(8)}$, Comput Inform Nurs ${ }^{(9)}$, Breast ${ }^{(10)}$, JMIR Mhealth UHealth ${ }^{(11)}$ and Surg Technol Int ${ }^{(12)}$.

Regarding the location and origin of the studies, three (60\%) were conducted in the United States ${ }^{(8,11-12)}$, one
(20\%) in Ireland ${ }^{(10)}$ and one $(20 \%)$ in South Korea ${ }^{(10)}$. The research designs of the included studies were: a randomized clinical trial ${ }^{(10)}$; a quasi-experimental pre- and post-test study ${ }^{(9)}$; a follow-up pilot study ${ }^{(12)}$; and a prospective cohort ${ }^{(8,11)}$.

Regarding the level of evidence according to the Oxford classification ${ }^{(7)}$, two studies presented an evidence recommendation of $\mathrm{A}$, with studies at level $1 \mathrm{~B}^{(10)}$ and $1 \mathrm{C}^{(9)}$, and three studies with recommendation $\mathrm{B}$, with studies at level $2 \mathrm{~B}^{(8,11)}$ and $2 \mathrm{C}^{(12)}$. 
The participants included in the studies had homogeneous sociodemographic characteristics regarding age, education and gender, except one study ${ }^{(10)}$ composed only of women. The sample size of the studies ranged from 17 to 123 participants, aged over 18 years. The sample size calculation was performed in four $(80 \%)$ studies $^{(8-11)}$. General surgery $^{(9)}$, bariatric $^{(8)}$, urological $^{(9)}$, neurological ${ }^{(9)}$, orthope$\mathrm{dic}^{(9,12)}$, breast cancer ${ }^{(10)}$ and coloproct ${ }^{(11)}$ surgery patients were addressed.

Chart 2 presents a synthesis of the studies included in the review containing the author(s), sample, objective, intervention, measuring instrument, result and level of evidence.

Chart 2 - Summary of studies included in the review.

\begin{tabular}{|c|c|c|c|c|c|c|}
\hline Author & $\mathbf{N}$ & Objective & Intervention & Measuring instrument & Result & $\begin{array}{c}\text { Evidence } \\
\text { level }\end{array}$ \\
\hline $\begin{array}{c}\text { Mundi et } \\
\text { al.(8) }\end{array}$ & 30 & $\begin{array}{c}\text { Evaluate the acceptability } \\
\text { and effectiveness of a } \\
\text { mobile app in preparing } \\
\text { patients for bariatric } \\
\text { surgery. }\end{array}$ & $\begin{array}{c}\text { Mobile application with } \\
\text { videos and messages, } \\
\text { preoperatively. Application } \\
\text { of the knowledge test before } \\
\text { the intervention and after } 12 \\
\text { weeks. Physical activity and } \\
\text { usability test applied after } 12 \\
\text { weeks. }\end{array}$ & $\begin{array}{c}\text { Knowledge Test } \\
\text { International Physical } \\
\text { Activity Short Form } \\
\text { Questionnaire } \\
\text { (IPAQ-SF)/Instrument } \\
\text { developed by the } \\
\text { researcher regarding } \\
\text { usability. }\end{array}$ & $\begin{array}{c}\text { Only } 10 \text { patients completed the } \\
\text { study. There was an increase in } \\
\text { nutritional knowledge, and greater } \\
\text { engagement in a healthy lifestyle. } \\
\text { Application adapted to the patient's } \\
\text { daily routine, was useful for surgery } \\
\text { preparation, patients reported } \\
\text { better connection with the surgical } \\
\text { team. }\end{array}$ & $2 \mathrm{~B}$ \\
\hline Cho, Lee(9) & 123 & \begin{tabular}{|c|} 
To evaluate the \\
knowledge acquired \\
using the Safe patients \\
mobile app in patients \\
undergoing general, \\
urological, orthopedic \\
and neurological surgery.
\end{tabular} & $\begin{array}{c}\text { Application usage for } 3 \text { days. } \\
\text { Evaluation moment: before } \\
\text { and after } 3 \text { days. }\end{array}$ & $\begin{array}{c}\text { Instrument developed } \\
\text { by the researcher with } \\
\text { seven true and false } \\
\text { questions about patient } \\
\text { safety. }\end{array}$ & $\begin{array}{l}\text { Average correct answers pre-test } \\
\text { of } 64.8 \% \text { and post-test of } 75.8 \% \\
\qquad(p<0.001)\end{array}$ & $1 \mathrm{C}$ \\
\hline $\begin{array}{c}\text { Foley et } \\
\text { al.(10) }\end{array}$ & $\begin{array}{c}39 \\
\mathrm{IG}=13 \\
\mathrm{CG}=26\end{array}$ & $\begin{array}{c}\text { Evaluate the effectiveness } \\
\text { of using an iPad app } \\
\text { to reduce anxiety and } \\
\text { depression in patients } \\
\text { undergoing mastectomy. }\end{array}$ & $\begin{array}{c}\text { IPad app with information, } \\
\text { animations and comfort } \\
\text { messages. Time of } \\
\text { assessment: one week before } \\
\text { surgery, when they received } \\
\text { iPad, and postoperatively } \\
\text { after one week, in routine } \\
\text { outpatient consultations. }\end{array}$ & \begin{tabular}{|} 
Hospital Anxiety and \\
Depression Scale \\
(HADS)/ \\
Mini-Mental \\
Adjustment to Cancer \\
(Mini-MAC)/ \\
The Information \\
Technology Familiarity \\
Questionnaire/ \\
Information Satisfaction \\
Questionnaire.
\end{tabular} & \begin{tabular}{|} 
Homogeneous groups in the \\
preoperative HADS scale score \\
and immediate postoperative, \\
but significantly lower in the \\
control group patients in the 7 th \\
postoperative period ( $\mathrm{p}=0.029$ for \\
anxiety and 0.022 for depression). \\
There was no significant difference \\
in 4 of the 5 domains of the Mini- \\
MAC questionnaire. \\
Satisfaction with the information \\
received by the application was \\
similar between the pre and \\
postoperative groups.
\end{tabular} & $1 \mathrm{~B}$ \\
\hline $\begin{array}{l}\text { Scott et } \\
\text { al.(11) }\end{array}$ & 20 & \begin{tabular}{|c|} 
To evaluate the interest \\
in using self-reporting \\
mobile applications and \\
warning sign screening in \\
patients after colorectal \\
surgery and to better \\
understand the factors \\
that affect postoperative \\
use of the application at \\
home.
\end{tabular} & $\begin{array}{c}\text { Application presented to } \\
\text { the patient upon admission } \\
\text { and instructed to use daily } \\
\text { for } 2 \text { weeks after hospital } \\
\text { discharge. (There was a } \$ 10 \\
\text { incentive to use). }\end{array}$ & $\begin{array}{c}\text { System Usability Scale } \\
\text { (SUS)/Semi-structured } \\
\text { interview. }\end{array}$ & \begin{tabular}{|} 
Loss of five patients. SUS scale \\
score of 95 . Interview results: $75 \%$ \\
daily use; frequency of use: $80 \%$ at \\
least seven times and $26.7 \%$ over \\
25 times. Overall impression: The \\
app serves as a second opinion \\
or supplement to the information \\
received previously.
\end{tabular} & 2B \\
\hline $\begin{array}{l}\text { Kim et } \\
\text { al.(12) }\end{array}$ & 17 & $\begin{array}{l}\text { To evaluate the } \\
\text { effectiveness of the } \\
\text { mobile application } \\
\text { with the iGetBetter } \\
\text { (iGB) program as an } \\
\text { alternative to support } \\
\text { and encourage patients } \\
\text { for better adherence } \\
\text { to the preoperative } \\
\text { and postoperative total } \\
\text { knee arthroplasty (TKA) } \\
\text { protocol. }\end{array}$ & $\begin{array}{c}\text { Provided an iPad mini to } \\
\text { the patients with internet to } \\
\text { access the app. Patients used } \\
\text { the app in self-preparation } \\
\text { and perioperative recovery, } \\
\text { with manual data recording } \\
\text { on the iPad mini. Data to } \\
\text { be recorded: execution of } \\
\text { the care plan during the } \\
\text { day; response to common } \\
\text { reminders in pre- and } \\
\text { postoperative TKA protocols } \\
\text { received by the application. }\end{array}$ & \begin{tabular}{|} 
IGB Clinical \\
Dashboard, the system \\
triggers alerts to the \\
clinician if patients \\
provide answers out \\
of range of what the \\
clinician considers \\
acceptable. \\
\end{tabular} & $\begin{array}{c}\text { In the } 14 \text { days before the operation, } \\
92.3 \% \text { of the patients participated } \\
\text { in the education accesses ( } \mathrm{n}=6 \text { ), } \\
\text { a necessary amount, with an } \\
\text { average of } 3.5 \text { and a } 59 \% \text { reduction } \\
\text { in adherence. Postoperatively } \\
\text { there was an average of } 17.8 \\
\text { accesses in } 30 \text { days ( } 59.2 \% \text { ), } \\
\text { with no significant difference } \\
\text { between the number of accesses } \\
\text { in the preoperative phase. } 2,045 \\
\text { responses ( } 157 \text { answers per patient) } \\
\text { were given to } 3,984 \text { specific } \\
\text { instructions considering patient } \\
\text { losses (307 questions per patient), } \\
\text { involving consultations and } \\
\text { follow-up, which resulted in a } 51 \% \\
\text { response rate. }\end{array}$ & $2 \mathrm{C}$ \\
\hline
\end{tabular}

Three (60\%) studies applied the intervention in the preoperative and postoperative periods ${ }^{(8,10,12)}$, while two (40\%) others employed the postoperative intervention ${ }^{(9,11)}$. These interventions were performed through the contents contained in the applications such as videos, messages, reminders and animations which used information from educational protocols in the pre and post-operative periods.

Four (80\%) studies used mobile apps developed in the English language ${ }^{(8,10-12)}$, and one application was produced in the Korean language ${ }^{(9)}$. 
The studies included in this review have named the apps and made them available in their free version. Two (20\%) used applications available on the Apple (iOS) and Google (Play Store) platforms ${ }^{(8,11)}$ with their respective names "Smartphone app" and "mHealth"; one named the app "GraphPad" (10) and another named "iGetBetter" ${ }^{(12)}$, and both used the Apple (iOS) platform. The "Safe Patients" app ${ }^{(9)}$ did not cite an available platform.

Regarding application components, studies generally focused interventions through messages, images, animations, information on surgical techniques, treatments, questionnaires, and even games. These interventions were used to promote surgical patient health education, so that each study structured its application to the observed sample with the intention of employing surgical orientation in the perioperative period, as presented above in the study summary chart.

The mobile applications used for educating and orientating the surgical patient were effective in $60 \%$ of the publications, the employed interventions improved the patients' knowledge about the procedure and care in the pre- and post-operative periods.

\section{DISCUSSION}

Few studies answered the guiding question. Recent publications connote a new area of research which is little explored by health professionals.

Although the studies had a small sample size and the results cannot be generalized, the studies show positive results regarding the acquired knowledge ${ }^{(8-9)}$, user satisfaction $^{(10-11)}$ and the adherence rate to the guidelines ${ }^{(12)}$.

One study ${ }^{(13)}$ on patient evaluation of mobile apps found that the most commonly used health apps covered the topics of exercise, diet and puzzles. Although participants more often shared information about health applications on their social networks, information was shared less frequently with providers, and medical recommendation played a small role in influencing patient use of health applications ${ }^{(13)}$.

However, a review on the use of other technologies, such as patient education leaflets, concluded that whatever the clinical situation, leaflets improve patient knowledge and satisfaction. Short-term leaflets improve treatment adherence for acute conditions, while their impact on adherence varies depending on the context, how the leaflets are administered and the invasiveness of the intervention for chronic diseases, invasive procedures or screening situations ${ }^{(14)}$.

Tablets and mobile phones are becoming increasingly popular with users nowadays. The number of applications has increased significantly, including applications used as methods to meet health needs. These applications are becoming viable and useful tools for the care of surgical patients, enabling their communication with health professionals regarding the transmission of information and care guidance ${ }^{(15)}$.

One study ${ }^{(9)}$ which used games and safety questions in the application showed a significantly higher percentage of correct patient answers when comparing the two preand post-intervention moments. The study emphasized the importance of nurses' approval and participation in application development ${ }^{(9)}$.

Another study ${ }^{(10)}$ reported advantages in mobile applications compared to traditional methods of information dissemination, such as brochures and websites. Among these advantages is the amount of individuals who can be reached and benefited with the information contained in these mobile tools, anywhere in the world.

Mobile devices are globally interconnecting people everywhere, no matter where they are. This interconnection enables an unprecedented ability to improve health communication. An example of this improvement is smartphone apps to monitor and diagnose diseases, as well as to bring patients and healthcare professionals even closer ${ }^{(16)}$.

It is estimated that approximately over 500 million people have their own smartphone, meaning that mobile tools are expanding among professionals and patients for health education and disease monitoring ${ }^{(17)}$.

One limitation found in this integrative review was the absence of research with robust designs, considering that the best evidence is obtained through studies with high methodological quality.

\section{CONCLUSION}

Studies on the use of patient education applications are recent. Publications from the last 2 years show that the use of messages, videos, images and animations are the resources inserted in applications for smartphones or tablets which are being used in educating surgical patients. The studies confirm that such tools present effective intervention results regarding perioperative knowledge and care.

It is important to discuss the theme and the applicability of these tools in health education and self-care of surgical patients more frequently. The need for further research in the nursing area using new communication technologies is also emphasized.

\section{RESUMO}

Objetivo: Analisar a literatura científica produzida sobre educação em saúde por meio de aplicativos de celular para pacientes cirúrgicos. Método: Revisão integrativa da literatura, realizada por meio de consulta nos portais e/ou bases de dados: BVS; PubMed; Web of Science; Scopus; LILACS e CINAHL. A busca foi norteada pela pergunta: "Quais as evidências do uso de aplicativos em celulares na educação em saúde de pacientes cirúrgicos?” e realizada no período de julho a setembro de 2017 , incluindo artigos publicados a partir do ano de 2000 até 2017. Resultados: Foram selecionados cinco artigos publicados em periódicos internacionais em inglês, com desenhos metodológicos variados. Entre os estudos encontrados, $60 \%$ utilizaram a intervenção educativa por meio de aplicativos de smartphone nos períodos pré e pós-operatório. Observou-se que 40\% dos estudos tiveram nível de evidência 2B. Conclusão: Os estudos mostraram que o uso de aplicativos de smartphone na educação e orientação do paciente cirúrgico foi efetivo. Ainda assim, há uma lacuna de estudos que evidenciem a prática de educação do paciente cirúrgico por meio de aplicativos de smartphone.

\section{DESCRITORES}

Assistência Perioperatória; Educação em Saúde; Aplicativos Móveis; Smartphone; Enfermagem Perioperatória; Revisão. 


\section{RESUMEN}

Objetivo: Analizar la literatura científica producida acerca de la educación en salud por medio de aplicaciones de teléfono celular para pacientes quirúrgicos. Método: Revisión integrativa de la literatura, realizada mediante consulta en las páginas web y/o bases de datos: BVS; PubMed; Web of Science; Scopus; LILACS y CINAHL. La búsqueda fue orientada por la pregunta: “;Cuáles son las evidencias del empleo de aplicaciones de teléfonos celulares en la educación en salud de pacientes quirúrgicos?" y llevada a cabo en el período de julio a septiembre de 2017, incluyéndose artículos publicados desde el año 2000 hasta el 2017. Resultados: Fueron seleccionados cinco artículos publicados en periódicos internacionales en inglés, con diseños metodológicos variados. Entre los estudios encontrados, el 60\% utilizaron la intervención educativa mediante aplicaciones de smartphone en los períodos pre y posoperatorio. Se observó que el 40\% de los estudios presentaron nivel de evidencia 2B. Conclusión: Los estudios mostraron que el empleo de aplicaciones de smartphone en la educación y orientación del paciente quirúrgico fue efectivo. Aun así existe una laguna de estudios que evidencien la práctica de educación del paciente quirúrgico mediante aplicaciones de smartphone.

\section{DESCRIPTORES}

Atención Perioperativa; Educación en Salud; Aplicaciones Móviles; Teléfono Inteligente; Enfermería Perioperatoria; Revisión.

\section{REFERENCES}

1. Salci MA, Maceno P, Rozza SG, Silva DMGV, Boehs AE, Heidemann ITSB. Educação em saúde e suas perspectivas teóricas: algumas reflexões. Texto Contexto Enferm. 2013;22(1):224-30. DOI: 10.1590/S0104-07072013000100027.

2. Amthauer C, Nora TTD, Souza TP, Fernandes CR, Nogueira QDS, Martins LB. Atividades de Educação em Saúde com pacientes cirúrgicos em um hospital universitário: relato de Experiência. Rev Contexto Saúde. 2013;11(20):705-10. DOI: 10.21527/2176-7114.2011.20.705-710.

3. Associação Brasileira de Enfermeiros de Centro Cirúrgico, Recuperação Anestésica e Centro de Material e Esterilização (SOBECC). Diretrizes de Práticas em Enfermagem Cirúrgica e processamento de produtos para a saúde. $7^{\mathrm{a}}$ ed. São Paulo: Atheneu; 2017.

4. Singh RA, McGrath MC. Education for practitioners and patients. Australas Med J. 2013;6(12):724-6. DOI: 10.4066/AMJ.2013.1952

5. Moura CDA, Greco RM, Leonel M. Saúde do trabalhador: produção científica da enfermagem na primeira década do século XXI. Rev Enferm UFJF [Internet]. 2016 [citado 2018 mar. 12];1(2). Disponível em: https://periodicos.ufff.br/index.php/enfermagem/article/ view/3800/1575

6. Ursi ES, Galvão CM. Prevenção de lesões de pele no perioperatório: revisão integrativa da literatura. Rev Latino Am Enfermagem. 2006;14(1):124-31. DOI: 10.1590/S0104-11692006000100017.

7. Centre for Evidence-Based Medicine. Levels of evidence [Internet]. Oxford; 2009 [cited 2018 Mar 05]. Available from: http://www.cebm. net/oxford-centre-evidence-based-medicine-levels-evidence-march-2009/

8. Mundi MS, Lorentz PA, Grothe K, Kellog TA, Collazo-Clavell ML. Feasibility of smartphone-based education modules and ecological momentary assessment \intervention in pre-bariatric surgery patients. Obes Surg. 2015;25(10):1875-81.DOI: 10.1007/s11695-015-1617-7

9. Cho S, Lee E. Effects of the smartphone application "Safe Patients" on knowledge of patient safety issues among surgical patients. Comput Inform Nurs. 2017;35(12):639-46. DOI: 10.1097/CIN.0000000000000374

10. Foley NM, O'Connell EP, Lehane EA, Livingstone V, Maher B, Kaimkhane S. et al. PATI: Patient accessed tailored information: a pilot study to evaluate the effect on preoperative breast cancer patients of information delivered via a mobile application. Breast. 2016;30:54-8. DOI: 10.1016/j.breast.2016.08.012

11. Scott AR, Aloe EA, Naik AD, Berger DH, Suliburk JW. Mixed-methods analysis of factors impacting use of a postoperative mHealth app. JMIR mHealth uHealth. 2017;5(2):e11. DOI: 10.2196/mhealth.6728

12. Kim K, Pham D, Schwarzkopf R. Mobile application use in monitoring patient adherence to perioperative total knee arthroplasty protocols. Surg Technol Int. 2016;28:253-60.

13. VonHoltz LA, Hypolite KA, Carr BG, Shofer FS, Winston FK, Hanson CW, et al. Use of mobile apps: a patient-centered approach. Acad Emerg Med. 2015;22(6):765-8. DOI: 10.1111/acem.12675

14. Sustersic M, Gauchet A, Foote A, Bosson JL. How best to use and evaluate Patient Information Leaflets given during a consultation: a systematic review of literature reviews. Health Expect. 2017;20(4):531-42. DOI: 10.1111/hex.12487

15. Wu JM, Yu HJ, Ho TW, Su XY, Lin MT, Lai F. Tablet PC-enabled application intervention for patients with gastric cancer undergoing gastrectomy. Computer Methods Programs Biomed. 2015;119(2):101-9. DOI: 10.1016/j.cmpb.2015.03.004

16. Steinhubl SR, Muse ED, Topol EJ. Can mobile health technologies transform health care? JAMA. 2013;310(22):2395-6.DOI: 10.1001/ jama.2013.281078.

17. Simpao AF, Lingappan AM, Ahumada LM, Rehman MA, Galvez JA. Perioperative Smartphone Apps and Devices for Patient-Centered Care. J Med Syst. 2015;39(9):102. DOI: 10.1007/s10916-015-0310-7 